\title{
NOTE
}

\section{Effect of light/dark transition on carbon translocation in eelgrass Zostera marina seedlings}

\author{
Richard C. Zimmerman ${ }^{1, *}$, Randall S. Alberte ${ }^{2}$ \\ ${ }^{1}$ Biology Department, University of California at Los Angeles, Los Angeles, California 90024, USA \\ ${ }^{2}$ Biological Science and Technology Program, Office of Naval Research, 800 N. Quincy St., Arlington, Virginia 22217, USA
}

\begin{abstract}
Carbon translocation in the marine macrophyte Zostera marina L. (eelgrass) was investigated to elucidate the impact of light/dark transitions on sucrose partitioning between roots and shoots. After exposure of leaves to ${ }^{14} \mathrm{C}$ bicarbonate, the level of ${ }^{14} \mathrm{C}$-labelled photoassimilates increased monotonically in both leaves and fully aerobic roots of plants maintained in the light. Accumulation of ${ }^{14} \mathrm{C}$ in roots and leaves ceased abruptly when plants were transferred to darkness that induced root anaerobiosis even though ${ }^{17} \mathrm{Clev}$ els remained high in the dark-exposed leaves. Thus, translocation of ${ }^{14} \mathrm{C}$ photoassimilates from shoots to roots was inhibited when roots became anoxic. Anoxia induced by light limitation of photosynthesis, whether due to day/night transitions or periods of extreme light attenuation in the water column, can have an impact on carbon availability in subterranean tissues of eelgrass. As a consequence, light availability is likely to control the productivity and distribution of eelgrass in highly variable and light-limited coastal environments through its effects on carbon partitioning between shoots and roots, in addition to whole-plant carbon balance
\end{abstract}

KEY WORDS: Seagrass · Anoxia - Translocation - Light Photosynthesis - Carbon transport

The relationship between light availability and depth distribution/productivity of marine autotrophs is fundamental to the dynamics of primary production in the sea, and is embodied in the concept of critical depth (Sverdrup 1953). This balance of photosynthesis, respiration and growth is commonly invoked to explain the distribution, abundance and productivity of phytoplankton, macrophytic algae and seagrasses (Lüning 1981, Peckol \& Ramus 1988, Duarte 1991, Platt et a]. 1991).

The role of light availability in regulating the productivity and colonization depth of seagrasses is well established (reviewed by Duarte 1991), but the proxi-

-Correspondence address: Hopkins Marine Station, Pacific Grove, California 93950, USA. E-mail: rzimmer197@aol.com mate physiological mechanisms influenced by light limitation are not always clear. Whole-plant carbon balance should limit colonization depths to a single isolume according to the critical depth concept. Different mean light requirements, however, are frequently reported for the same species of seagrasses growing in different habitats (Borum 1983, Dennison 1987, 1991, Kenworthy et al. 1991, Zimmerman et al. 1991). This suggests that light availability must regulate ecological success and colonization depths through mechanisms that are more complex than assumed by the simple carbon balance model embodied in the concept of critical depth. Unlike non-vascular marine autotrophs, seagrasses invest considerable resources and biomass in non-photosynthetic tissues (roots and rhizomes) that depend strictly upon photosynthetic shoots for the translocation of reduced carbon for maintenance and growth, as well as the transport of photosynthetically produced $\mathrm{O}_{2}$ for aerobic respiration (Smith et al. 1984, Kraemer \& Alberte 1993). Consequently, eelgrass roots become anoxic every night and during the daytime when low light levels severely limit photosynthetic $\mathrm{O}_{2}$ production (Smith et al, 1984). While anoxic, sucrose consumption via fermentation in eelgrass roots is reduced to $65 \%$ of the aerobic rate (Smith et al. 1988), the adenylate energy charge drops to very low levels (Smith 1989) and rates of protein synthesis are reduced (Smith 1989, Kraemer \& Alberte 1995). The return to full aerobic activity occurs within a few minutes after roots are re-oxygenated, even after many hours of anaerobiosis (Pregnall et al. 1987. Smith et al. 1988, Kraemer \& Alberte 1995).

The ability of eelgrass roots to tolerate anoxia depends strictly on the availability of sucrose reserves imported from the shoot to maintain fermentative energy production throughout the anoxic period (Smith et al. 1988, Smith 1989). Anoxia, however, in- 
hibits phloem translocation in many vascular plants which is driven by mitochondrial respiration in phloem companion cells (Geiger \& Sovonick 1975, Jackson \& Drew 1984, Saglio 1985, Van Bel 1993). Acropetal transport (via xylem) of inorganic $\mathrm{PO}_{4}{ }^{-3}$ taken up by roots of Zostera marina and $Z$. noltii is strongly lightdependent (McRoy \& Barsdate 1970, Penhale \& Thayer 1980, Brix \& Lingby 1985, Pérez-Lloréns et al. 1993). The impact of light and root aerobic status on basipetal translocation of photosynthates in seagrasses that possess metabolic and structural adaptations for anoxia tolerance, however, is not well understood.

Here we sought to determine the impact of darkness-induced root anoxia on translocation of ${ }^{14} \mathrm{C}$ photoassimilates from leaves to roots of eelgrass seedlings. If translocation is $\mathrm{O}_{2}$-dependent in seagrasses, then prolonged daily anoxia resulting from light limitation of photosynthetic $\mathrm{O}_{2}$ production may produce carbon limitation in roots, even though whole-plant carbon balance remains favorable (Pregnall et al. 1987, Smith et al. 1988, Zimmerman et al. 1991). Subterranean anoxia may also block the mobilization of stored sucrose from rhizomes to growing shoots and roots, particularly in the spring when growth rates increase and carbon demand is high (Zimmerman et al. 1995b, and references cited therein). Thus, the survival of eelgrass in unpredictable light environments may depend on the extent to which nighttime anoxia and periods of extreme daytime light attenuation disrupt the partitioning and flux of sucrose between shoots, roots and rhizomes (Zimmerman et al. 1991, 1994).

Materials and methods. Zostera marina L. seedlings were collected by hand from an intertidal population in San Francisco Bay, California, USA. Plants were gently

\section{Quartz-Halogen Lamp}

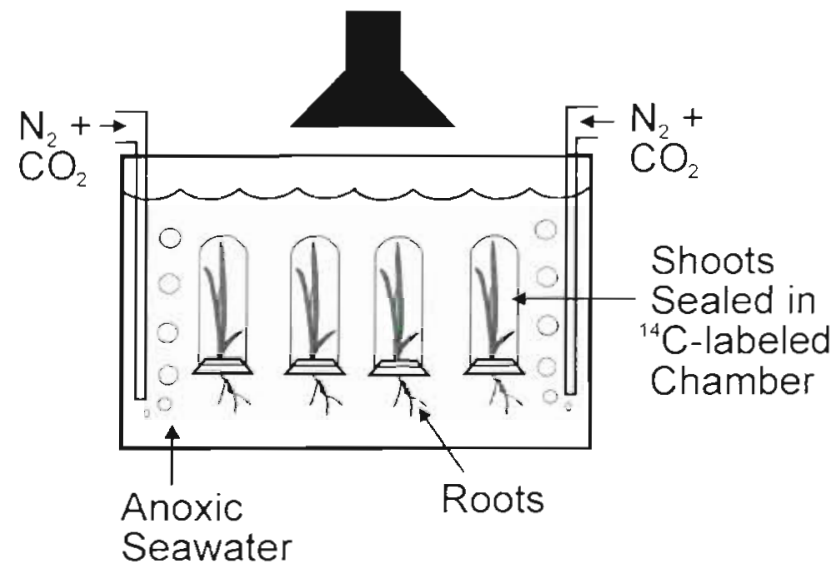

Fig. 1. Diagram of experimental apparatus for translocation experiments in Zostera marina removed from the sediment without breaking root tips and transported to the laboratory at Hopkins Marine Station, Pacific Grove, California, where they were threaded individually through holes ( $3 \mathrm{~mm}$ diameter) punched in silicone rubber stoppers. The remaining gap around each hypocotyl was sealed with silicone grease to prevent leakage of ${ }^{14} \mathrm{C}$-bicarbonate into the anaerobic root chamber The shoots were sealed into $50 \mathrm{ml}$ glass incubation tubes filled with filtered $(0.2 \mu \mathrm{m})$ seawater (FSW) and $50 \mu \mathrm{Ci}{ }^{14} \mathrm{C}$-bicarbonate. The tubes were placed into an incubator filled with anoxic FSW bubbled continuously with compressed $\mathrm{CO}_{2}(350 \mathrm{ppm})+\mathrm{N}_{2}$ (balance) to maintain an external anderobic environment for the roots (Fig. 1). The $\mathrm{O}_{2}$ concentration in the incubator was monitored by a polarographic $\mathrm{O}_{2}$ electrode and remained below $5 \%$ of air saturation throughout the experiment. Photosynthesis-saturating irradiance (500 $\mu \mathrm{mol}$ quanta $\mathrm{m}^{-2} \mathrm{~s}^{-1}$ ) was provided by a quartz-halogen lamp to drive photosynthesis and maintain root oxygenation (Smith et al 1984). Incubation temperature was maintained at $15^{\circ} \mathrm{C}$ (ambient field temperature) using a circulating water bath

Individual plants in tubes were removed at random every 20 min for evaluation. Root bundles were cut immediately from shoots before removing stoppers. After $3 \mathrm{~h}$ in the light, half the remaining tubes were transferred to an identical incubator filled with anoxic FSW bubbled with $\mathrm{N}_{2}+\mathrm{CO}_{2}$, but darkened to induce root anoxia. The other tubes were maintained in the light to maintain root aerobiosis. Sampling was continued at 20 min intervals for $3 \mathrm{~h}$. Roots and shoots were weighed, ground separately in $\mathrm{dH}_{2} \mathrm{O}\left[20 \mathrm{ml} \mathrm{g}^{-1}\right.$ fresh weight (FW)], digested with an equal volume of NCS (Reg. Amersham Co.), and acidified with $1 \mathrm{~N} \mathrm{HCl}$. Radioactivity of acid-stable tissue homogenates was determined by liquid scintillation counting. Quench corrections were performed according to the sample channels ratio.

Results and discussion. Accumulation of ${ }^{14} \mathrm{C}$-labeled photoassimilates in shoots was linear for the first $5 \mathrm{~h}$ of illumination (Fig. 2). Shoot ${ }^{14} \mathrm{C}$ content declined after $5 \mathrm{~h}$, indicating that photosynthetic $\mathrm{CO}_{2}$ assimilation became substrate-limited and/or $\mathrm{O}_{2}$-inhibited in the last $90 \mathrm{~min}$ of the experiment. Leaf ${ }^{14} \mathrm{C}$ concentration appeared to drop slightly after transfer to darkness, suggesting loss due to respiration or translocation (Fig 2). The decline, however, was not statistically significant (regression ANOVA, $F=3.76, \mathrm{df}=1,8, \mathrm{p}=$ 0.09). Thus there was no measurable ${ }^{14} \mathrm{C}$ uptake or loss by shoots when plants were held in the dark for $>3 \mathrm{~h}$. In contrast. high rates of sucrose translocation to sink tissues result in rapid nighttime depletion of leaf sucrose in many anoxia-intolerant species like maize (Rufty et al. 1983, Kalt-Torres \& Huber 1987). 


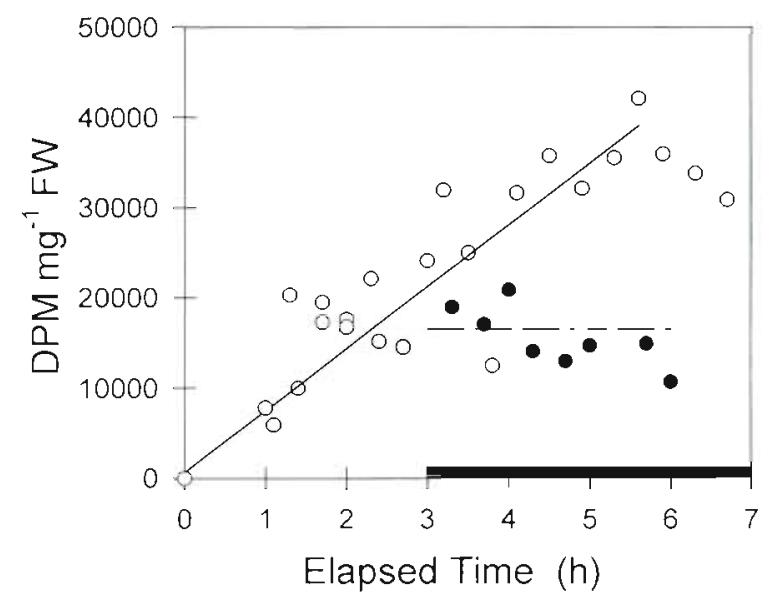

Fig. 2. Zostera marina. Accumulation of ${ }^{14} \mathrm{C}$ in eelgrass shoots. (O) Plants maintained in the light for $7 \mathrm{~h}$. () Plants transforred to darkness at $3 \mathrm{~h}$. The dark bar along the horizontal axis indicates the transfer of half the plants to darkness

The rate of ${ }^{14} \mathrm{C}$ accumulation in aerobic roots of illuminated eelgrass leaves followed an exponential tra-

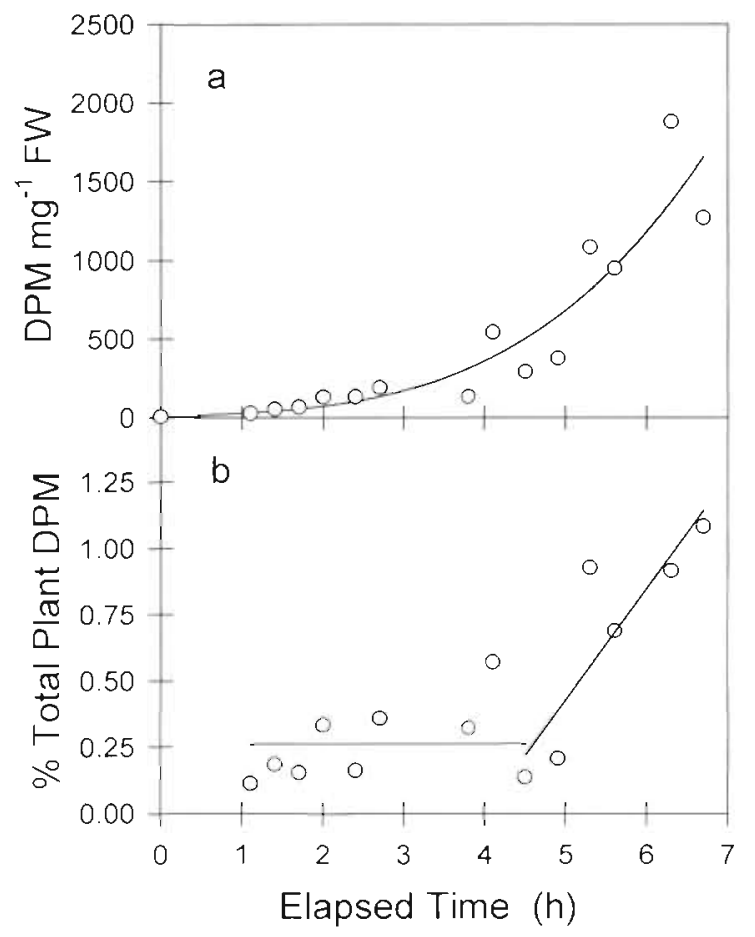

Fig. 3. Zostera marina. (a) Biomass-specific accumulation of ${ }^{14} \mathrm{C}$ in eelgrass roots maintained under photosynthesis-saturating irradiance throughout the duration of the experiment. The line represents a 3rd-order polynomial of DPM (disintegrations per minute) regressed against time. (b) Root ${ }^{14} \mathrm{C}$ content plotted as a percentage of total plant ${ }^{14} \mathrm{C}$. Horizontal line between 1 and $4.5 \mathrm{~h}$ represents the mean percentage during that time, while the line from 4.5 to $6.6 \mathrm{~h}$ was determined by linear regression jectory due to the lag between photosynthetic assimilation of ${ }^{14} \mathrm{C}$ into sucrose by shoots and the translocation of ${ }^{14} \mathrm{C}$ to the roots (Fig. 3a). The rate of ${ }^{14} \mathrm{C}$ accumulation in the roots was non-linear but monotonic as long as plants were held in continuous light. The fraction of ${ }^{14} \mathrm{C}$ found in the roots remained fairly constant at $0.26 \%( \pm 0.14 \%)$ of total plant ${ }^{14} \mathrm{C}$ for the first $5 \mathrm{~h}$. After $5 \mathrm{~h}$, however, root ${ }^{14} \mathrm{C}$ content increased dramatically to $1.2 \%$ of total plant ${ }^{14} \mathrm{C}$ (Fig. $3 \mathrm{~b}$ ). At this rate of acceleration, more than $10 \%$ of the ${ }^{14} \mathrm{C}$ fixed by leaves each day would be transported to roots that represent $<20 \%$ of biomass. This rapid increase in root ${ }^{14} \mathrm{C}$ after $5 \mathrm{~h}$ corresponded to loss of ${ }^{14} \mathrm{C}$ from the illuminated but photosynthesis-inhibited shoots in the last $90 \mathrm{~min}$ of the experiment. Thus, translocation in eelgrass may continue in the absence of photosynthetic carbon fixation provided roots are aerobic and translocation substrates (sucrose) remain in the leaves.

The levels of root ${ }^{14} \mathrm{C}$ continued to rise for about $1 \mathrm{~h}$ after plants were transferred to darkness (Fig, 4a). Unlike the roots of continuously illuminated shoots, however, root ${ }^{14} \mathrm{C}$ content did not change significantly

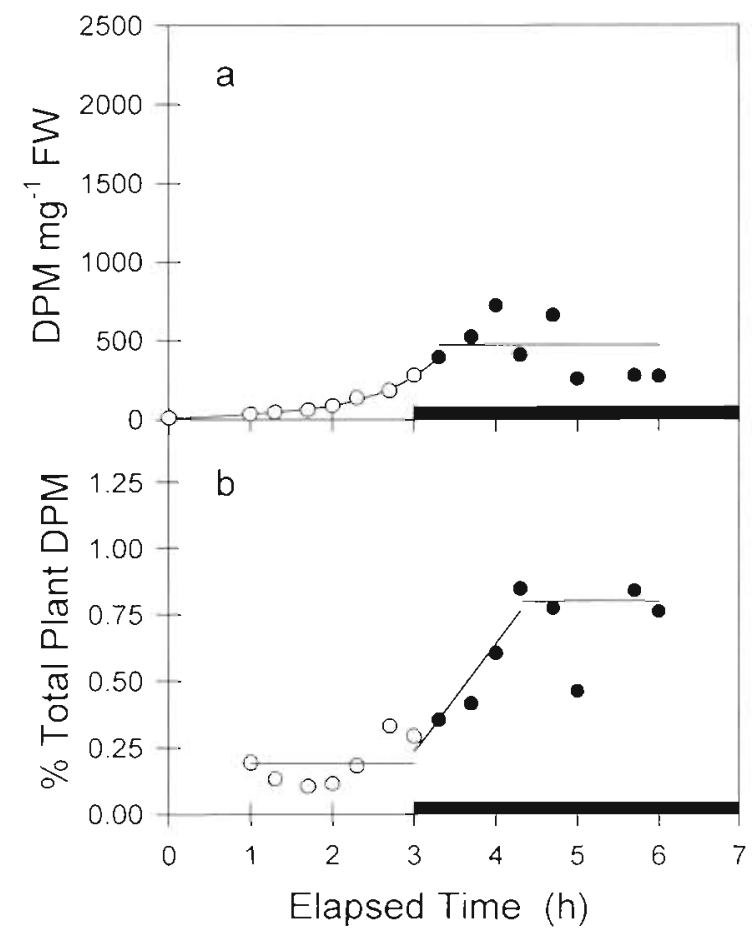

Fig. 4. Zostera marina. (a) Biomass-specific accumulation of ${ }^{14} \mathrm{C}$ in eelgrass roots transferred to darkness at $3 \mathrm{~h}$. Black bars along the elapsed time (horizontal) axis and - indicate the period of darkness and root anoxia. The curve before transfer to darkness represents a 3 rd-order polynomial regression of DPM against time. (b) Root ${ }^{14} \mathrm{C}$ content plotted as a percentage of total plant ${ }^{14} \mathrm{C}$. Horizontal lines from 1 to $3 \mathrm{~h}$ and 4.5 to $6.5 \mathrm{~h}$ represent the mean root percent DPM over those time intervals; the curve from 3 to $4.5 \mathrm{~h}$ was determined by linear regression of \%DPM against time 
after $1 \mathrm{~h}$ in the dark (Fig. 4a, regression ANOVA, $F=$ 4.92 , $\mathrm{df}=1,5, \mathrm{p}=0.07$ ). The fraction of total plant DPM (disintegrations per minute) in the roots in the darkexposed plants, however, increased significantly from 0.25 to $0.8 \%$ in the first hour after transfer to darkness (regression ANOVA, $F=25.12$, df $=1,3, p=0.015$ ) but remained constant after that (Fig. $4 \mathrm{~b}$ ). This indicates that translocation was maintained for about $1 \mathrm{~h}$ in the dark, during which time there was no ${ }^{14} \mathrm{C}$ fixation in the leaves. It is also consistent with the time required for fully aerobic roots to deplete lacunal $\mathrm{O}_{2}$ reserves and become anoxic after transfer to darkness (Smith et al. 1984, 1988).

Eelgrass roots do not increase rates of glycolytic carbon consumption to maintain ATP production under anoxia (i.e. no Pasteur effect) and carbon consumption decreases to $65 \%$ of the rate under aerobic respiration (Smith et al. 1988, Smith 1989). Reduced sucrose consumption by roots under anoxia conserves sucrose resources, thereby enhancing anoxia tolerance of eelgrass roots. In contrast, the dramatic Pasteur effect in anoxia-intolerant species such as maize and rice leads to rapid depletion of root sucrose pools (Jackson \& Drew 1984).

If translocation proceeded under darkness/hypoxia, levels of ${ }^{14} \mathrm{C}$ in darkened (anoxic) eelgrass roots should have been as high as in the aerobic roots of eelgrass plants maintained under photosynthesis-saturating levels of illumination. Since there was no significant accumulation of ${ }^{14} \mathrm{C}$ in eelgrass roots after $1 \mathrm{~h}$ in darkness, translocation in darkened plants was reduced precipitously once the roots became anoxic. Thus, phloem translocation is not maintained under root anoxia in eelgrass, despite the structural (e.g. lacunae) and metabolic (e.g no Pasteur effect) adaptations possessed by this species for growth in anoxic marine sediments

The inhibition of ${ }^{14} \mathrm{C}$ translocation during darkness in eelgrass seedlings probably results from cessation of respiratory activity in phloem mitochondria within the hypocotyl and root/rhizome rather than from a reduction in the source-sink gradient driving sucrose translocation. The relatively high and constant level of ${ }^{14} \mathrm{C}$ remaining in the darkened eelgrass leaves throughout the dark exposure period substantiates the lack of ${ }^{14} \mathrm{C}$ translocation from shoots to roots. It also indicates that depletion of sucrose by respiratory demand of darkened leaves is slow (Kraemer \& Alberte 1995, Zimmerman et al. 1995a). Translocation rates in anoxia-intolerant species often decrease at night as the leaf sucrose pool is depleted (Rufty et al. 1983, KaltTorres \& Huber 1987). In contrast to anoxia-intolerant species, sucrose levels in eelgrass leaves and roots do not exhibit a measurable response to light/dark transitions on a diel basis (Zimmerman et al. 1995a). Fur- thermore, sucrose levels in excised eelgrass roots can be sufficient to meet the requirements of anaerobic metabolism for as long as $3 \mathrm{~d}$ in the absence of any translocation (Smith 1989). The absence of significant carbon reserves in fast-growing species like maize means that even $1 \mathrm{~d}$ of low irradiance can produce carbon limitation in roots, leading to depressed rates of root respiration and nutrient uptake for $3 \mathrm{~d}$ or more after plants are returned to high irradiance (Massimino et al. 1981, Huber et al. 1989).

Sensitivity of ${ }^{14} \mathrm{C}$ translocation to darkness and below-ground anoxia in eelgrass has clear implications for carbon partitioning. The daily period of irradiancesaturated photosynthesis $\left(H_{\text {sat }}\right)$ can vary between 0 and $14 \mathrm{~h}$ from day to day in many eelgrass habitats (Zimmerman et al. 1991, 1994). Several consecutive days of light limitation (see Zimmerman et al. 1991, 1994) can prolong the daily period of root anoxia and block translocation, thereby inducing carbon limitation in roots even though carbon reserves in the shoot or rhizome source tissues may remain high. Consequently, it may be root sucrose, rather than shoot or rhizome reserves, that determines survival of these vascular macrophytes in aquatic environments characterized by unpredictable light availability and prolonged root anoxia.

Colonization depth limits of eelgrass in the field are likely influenced by the effect of light on translocation and carbon partitioning in addition to whole-plant carbon balance normally embodied in the concept of critical depth (Dennison 1987, Duarte 1991, Kenworthy et al. 1991). Consequently, environmental impacts on resource allocation between shoots and roots also must be considered in assessment of seagrass health and in the development of management strategies to promote growth, production and distribution of these ecologically important marine macrophytes.

Acknowledgements. We thank Robert D. Smith (Rutgers University) and G. Jason Smith (UCLA) for helpful comments and suggestions. This work was supported by the National Science Foundation under Grant No. OCE-9223265

\section{LITERATURE CITED}

Borum J (1983) The quantitative role of macrophytes, epiphytes and phytoplankton under different nutrient conditions on Rosskilde Fjord, Denmark. In: Proc Int Symp Aquat Macrophytes, Nijmegen, p 35-40

Brix H, Lingby JE (1985) Uptake and translocation of phosphorus in eelgrass (Zostera marina L.). Mar Biol 90:111-116

Dennison WC (1987) Effects of light on seagrass photosynthesis, growth and depth distribution. Aquat Bot 27:15-26

Dennison WC (1991) Photosynthetic and growth responses of tropical and temperate seagrasses in relation to Secchi depth, light attenuation and daily light period. In: Kenworthy WJ, Haunerts DE (eds) Results and recommenda- 
tions of a workshop convened to examine the capability of water quality criteria, standards and monitoring programs to protect seagrasses from deteriorating water transparency. Final report. South Florida Water Management District, West Palm Beach, p 133-144

Duarte CM (1991) Seagrass depth limits. Aquat Bot 40 $363-377$

Geıger DR, Sovonick SA (1975) Effects of temperature, anoxia and metabolic inhibitors on translocation. In: Zimmermann MH, Milburn JA (eds) Transport in plants. I. Phloem transport. Encycl Plant Physiol. Springer-Verlag, Berlin. p 260-286

Huber SC, Sugiyama T, Alberte RS (1989) Photosynthetic determinants of growth in maize plants: effects of nitrogen nutrition on growth, carbon fixation and photochemical features. Plant Cell Physiol 30:1063-1072

Jackson MB, Drew MC (1984) Effect of flooding on growth and metabolism of herbaceous plants. In: Kozlowski TT (ed) Flooding and plant growth. Academic Press, New York, p 47-128

Kalt-Torres W, Huber SC (1987) Diurnal changes in leaf maize photosynthesis. 1II. Leaf elongation in relation to carbohydrates and activities of sucrose metabolizing enzymes in elongating leaf tissue. Plant Physiol 83: $294-298$

Kenworthy WJ, Fonseca MS, DiPiero SJ (1991) Defining the ecological light compensation point for seagrasses Halodule wrightii and Syringodium filiforme from long term submarine light monitoring in the southern Indian River In: Kenworthy WJ, Haunerts DE (eds) Results and recommendations of a workshop convened to examine the capability of water quality criteria, standards and monitoring programs to protect seagrasses from deteriorating water transparency. Final report. South Florida Water Management District, West Palm Beach, p 98-105

Kraemer GP, Alberte RS (1993) Age-related patterns of metabolism and biomass in subterranean tissues of Zostera marina (eelgrass). Mar Ecol Prog Ser 95:193-203

Kraemer GP, Alberte RS (1995) Impact of daily photosynthetic period on protein synthesis and carbohydrate stores in Zostera marina L. (eelgrass) roots: implications for survival in light-limited environments. J Exp Mar Biol Ecol 185: $191-202$

Lüning K (1981) Photobiology of seaweeds: ecophysiological aspects. Proc Int Seaweed Symp 10:35-55

Massimino D, Andre M, Richaud C, Daguenet A, Massimino $J$, Vivoli J (1981) The effect of a day at low irradiance of a maize crop. I. Root respiration and uptake of N, P and K. Physiol Plant 51:150-155

McRoy CP, Barsdate RJ (1970) Phosphate absorption in eelgrass. Limnol Oceanogr 15:6-13

This note was submitted to the editor
Peckol P, Ramus J (1988) Abundance and physiological properties of deep-water seaweeds from Carolina outer continental shelf. J Exp Mar Biol Ecol 115:25-39

Penhale PA, Thayer GN (1980) Uptake and transfer of carbon and phosphorus by eelgrass (Zostera marina L.) and its epiphytes. J Exp Mar Biol Ecol 42:113-123

Pérez-Lloréns JL, de Visscher P. Nienhuis PH, Neill FX (1993) Light-dependent uptake, translocation and foliar release of phosphorus by the intertidal seagrass Zostera noltii Hornem. J Exp Mar Biol Ecol 166:165-174

Platt T, Bird DF, Sathyendranath S (1991) Critical depth and marine primary production. Proc R Soc Lond Ser (B) Biol Sci 246:205-218

Pregnall AM, Smith RD, Alberte RS (1987) Glutamine synthetase activity and tree amino acid pools of eelgrass (Zostera marina L.) roots. J Exp Mar Biol Ecol 106:211-228

Rufty TW, Kerr PS, Huber SC (1983) Characterization of diurnal changes in activities of enzymes involved in sucrose biosynthesis. Plant Physiol 73:428-4.33

Saglio PH (1985) Effect of path or sink anoxia on sugar translocation in roots of maize seedlings. Plant Physiol 77 : $285-290$

Smith RD (1989) Anaerobic metabolism in the roots of the seagrass Zostera marina $\mathrm{L}$. PhD dissertation, The University of Chicago

Smith RD, Dennison WC, Alberte RS (1984) Role of seagrass photosynthesis in root aerobic processes. Plant Physiol $74: 1055-1058$

Smith RD. Pregnall AM, Alberte RS (1988) Effects of anaerobiosis on root metabolism of the seagrass Zostera marina L. (eelgrass). Mar Biol 98:131-141

Sverdrup HU (1953) On conditions of the vernal blooming of phytoplankton. J Cons Explor Mer 18:287-295

Van Bel AJE (1993) Strategies of phloem loading. A Rev Plant Physiol Molec Biol 44:253-281

Zimmerman RC, Cabello-Pasini A, Alberte RS (1994) Modeling dally production of aquatic macrophytes from irradiance measurements: a comparative analysis. Mar Ecol Prog Ser 114:185-196

Zimmerman RC, Kohrs DG, Steller DL, Alberte RS (1995a) Carbon partitioning in the seagrass Zostera marina $\mathrm{L}$. regulation by photosynthesis and response to daily lightdark cycles. Plant Physiol 108:1665-1671

Zimmerman RC, Reguzzoni JL, Alberte RS (1995b) Eelgrass (Zostera marina L.) transplants in San Francisco Bay: role of light availability on metabolism, growth and survival. Aquat Bot 51:67-86

Zimmerman RC, Reguzzoni JL, Wyllie-Echeverria S, Josselyn M. Alberte RS (1991) Assessment of environmental suitability for growth of Zostera marina L. (eelgrass) in San Francisco Bay. Aquat Bot 39:353-366

Manuscript first received: December 27, 1995

Revised version accepted: Aprl 16, 1996 